\title{
The cycle of the seminiferous epithelium in Bali cattle (Bos sondaicus)
}

\author{
C. J. McCool \\ Berrimah Agricultural Research Centre, Department of Primary Industries and Fisheries, \\ P.O. Box 79, Berrimah, Northern Territory 0828 , Australia
}

\begin{abstract}
Summary. The duration of the cycle of the seminiferous epithelium in 5 mature Bali bulls was 11.75 days (standard error of estimate 0.52 days). The relative frequencies of the stages of the cycle of the seminiferous epithelium (morphological classification) of Bali cattle differed from other cattle and buffalo in that there were lower frequencies of Stage 1 and 2 tubules, and higher frequencies of Stage 3,6 and 7 tubules.
\end{abstract}

Keywords: Bali cattle; spermatogenesis; male fertility; seminiferous epithelium

\section{Introduction}

Bali cattle (Bos sondaicus) are a little-known species which in parts of southeast Asia (particularly Indonesia) are used for both meat production and agricultural power (Payne \& Rollinson, 1973). Little is known of the reproductive biology of this species. This paper reports results of investigations into the cycle of the seminiferous epithelium of Bali cattle

\section{Materials and Methods}

Five mature clinically normal Bali bulls were examined. Ages ranged from 3 to 9 years, and weights ranged from 290 to $450 \mathrm{~kg}$. Each bull was sedated with xylazine (Rompun: $2 \% \mathrm{w} / \mathrm{v}$ aqueous solution, $0.8 \mathrm{ml} / 45 \mathrm{~kg}$ bodyweight i.v.; Bayer Australia, Botany, NSW, Australia) and maintained in the standing position by slinging with ropes. Local anaesthesia was effected by the injection of $5 \mathrm{ml} 2 \%$ lignocaine hydrochloride with adrenaline into each spermatic cord. Tritiated thymidine solution $\left(\left[6-{ }^{3} \mathrm{H}\right]\right.$ thymidine, sp. act. 1.07 TBq/mmol; Radiochemical Centre, Amersham, Bucks, UK) was diluted in sterile normal saline $(0.154 \mathrm{M})$ so that each $5 \mathrm{ml}$ contained $18.5 \mathrm{MBq}(500 \mu \mathrm{Ci})$ of radioactivity. Then $5 \mathrm{ml}$ of this solution were injected into the testicular parenchyma at the ventral pole of each testis. Injection was performed using a 25 -gauge $\times 4 \mathrm{~cm}$ needle via 46 punctures of the scrotal skin and testicular parenchyma. Punctures were spaced approximately $1 \mathrm{~cm}$ apart. Each testis was biopsied once in the same region of the testis by puncture biopsy (Tru-cut disposable biopsy needles, $11.4 \mathrm{~cm}$ cannula, $20 \times 1.25 \mathrm{~mm}$ specimen notch; Travenol Laboratories, Inc, Deerfield, IL, USA). Figure 1 shows the time after injection at which the single biopsy was taken from each testis.

Samples were fixed in Cleland's fixative (Rowley \& Heller, 1966) and then embedded in paraffin wax; one 6- $\mu \mathrm{m}$ thick section from each testis was stained with haematoxylin and eosin. These were used to determine the relative frequencies of the stages of the cycle of the seminiferous epithelium. Tubules were classified according to the morphological classification of Roosen-Runge \& Giessel (1950) with substage classification by the method of Courot $e t$ al. (1970). Approximately 100 tubule cross-sections were classified in each of the 10 biopsies. The small amount of tissue harvested by the biopsy procedure prevented classification of a larger number of tubules.

Further sections from each biopsy specimen were coated with Kodak NTB2 Nuclear Tract Emulsion and exposed for 6 weeks. Slides were then developed in Kodak D19 Developer (1:1 developer:water, v/v) for 4 min. Development was stopped by immersion in distilled water for $10 \mathrm{sec}$. Slides were then fixed in Kodafix Liquid Fixer for 5 min, and washed in PBS for $5 \mathrm{~min}$. The temperature of all solutions used in the processing of the exposed slides was $15^{\circ} \mathrm{C}$. Slides were then stained with haematoxylin and eosin and mounted.

Each slide was examined to determine the stage and substage of tubules in which the most advanced labelled cell type was detected.

The duration of the cycle was estimated from a prediction equation developed as follows. The position of the labelled front in each testis was converted to a position relative to an arbitrarily selected point in the cycle of the seminiferous epithelium. For ease of calculation, the point selected was the beginning of Stage 1a. Thus the position of 
the labelled front relative to this reference point was expressed as the sum of the frequencies of all the stages from the beginning to Stage 1 up to and including the stage or substage wherein the labelled front was identified. The relationship between each of these positions and the corresponding time interval from injection of the label to the time of the biopsy were examined by linear regression analysis and plotted (Fig. 1). The resulting regression equation was used to predict (1) the time before injection at which this particular tubule cross-section would have been at the reference point (i.e. at Stage $1 \mathrm{a}, \%$ of cycle $=0$ ) and $(2)$ the time after injection at which the same tubule cross-section would again be at the arbitrary reference point (i.e. $\%$ of cycle $=100$ ). The interval between estimates $(1)$ and $(2)$ represents $100 \%$ of the cycle of the seminiferous epithelium (i.e. the duration of one cycle of the seminiferous epithelium).

Table 1. Relative frequencies of the stages and substages of the cycle of the seminiferous epithelium of the Bali bull

\begin{tabular}{lccc}
\hline Stage & Substage & $\begin{array}{c}\text { Relative } \\
\text { frequency (\%) }\end{array}$ & $\begin{array}{c}\text { Standard } \\
\text { error }\end{array}$ \\
\hline 1 & a & 6.04 & $1 \cdot 14$ \\
& b & 6.06 & 0.78 \\
2 & c & 5.82 & 0.26 \\
& a & 4.47 & $0 \cdot 10$ \\
3 & b & 5.48 & $0 \cdot 75$ \\
& a & 11.51 & 1.78 \\
4 & b & 15.84 & 1.72 \\
& a & 3.40 & 0.42 \\
5 & b & 4.21 & 0.77 \\
6 & & 4.04 & 0.56 \\
7 & & 12.82 & 1.12 \\
8 & & 13.19 & 1.44 \\
& a & 3.82 & 1.06 \\
& b & 3.31 & 0.91 \\
\hline
\end{tabular}

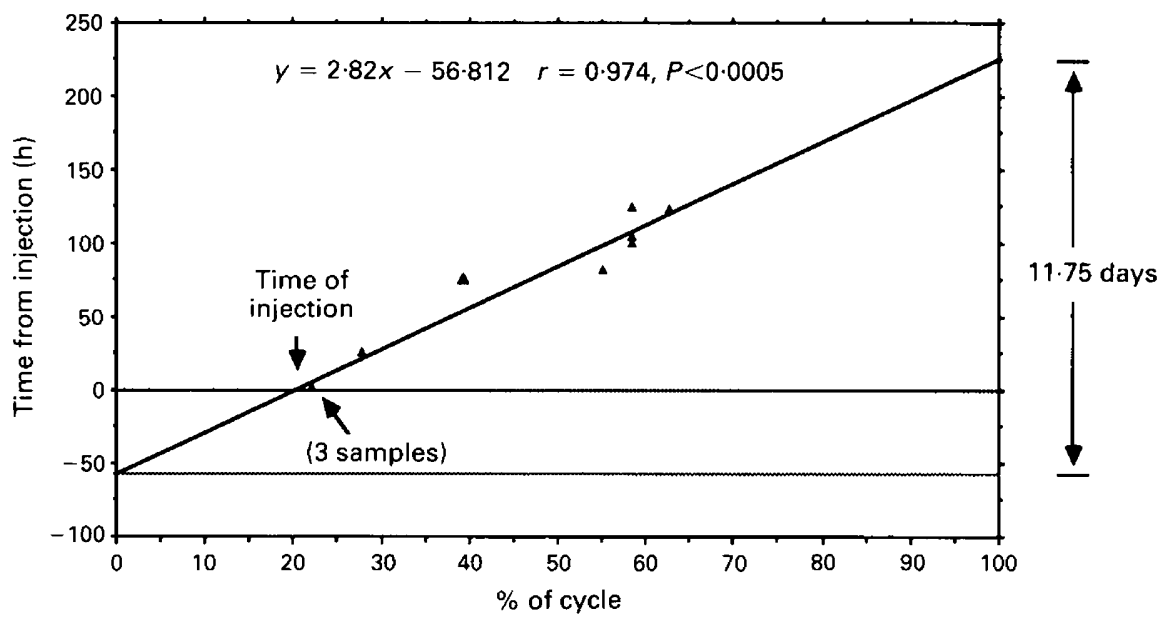

Fig. 1. The relationship between the time after injection of tritiated thymidine into the testicular parenchyma of Bali cattle and the most advanced labelled stage or substage identified.

\section{Results}

The cycle of the seminiferous epithelium in the Bali bull was similar to that of other domesticated ruminants in that the large majority of seminiferous tubule cross-sections contained distinct cellular associations representative of one specific stage or substage of the morphological classification, 
and all stages and substages were present in each section. It was therefore a simple procedure to adapt the morphological classification of testis tubules as adopted in other ruminants to testes from this species. Table 1 presents the relative frequencies of stages and substages of the cycle of the seminiferous epithelium in the Bali bull. None of the testicular sections exhibited seminiferous epithelial degeneration.

In testes sampled at $2 \mathrm{~h}$ after injection, the most advanced labelled cell type was the granular leptotene primary spermatocyte in substage $2 \mathrm{a}$. By $122 \mathrm{~h}$ after injection, the most advanced labelled cell type was the zygotene primary spermatocyte in substage $4 \mathrm{~b}$. The prediction equation was linear and statistically significant (Fig. 1). The estimated duration of the cycle of the seminiferous epithelium was 11.75 days (Fig. 1). The standard error of this estimate was 0.52 days.

\section{Discussion}

Table 2 provides comparative data on the durations of the cycles of the seminiferous epithelium and the relative frequencies of the stages in Bali cattle and several other ruminants. Bali cattle differ from the others in that they have lower frequencies of Stage 1 and 2 tubules, and higher frequencies of Stage 3,6 and 7 tubules (Table 2). The duration of the cycle of the seminiferous epithelium in the Bali bull is intermediate between those of buffalo and cattle (Table 3).

Table 2. Relative frequencies (\%) of the stages of the cycles of the seminiferous epithelium of buffalo and several species of cattle using the morphological classification, and durations of these cycles

\begin{tabular}{|c|c|c|c|c|c|c|c|c|c|}
\hline \multirow[b]{2}{*}{ Species } & \multicolumn{8}{|c|}{ Stage no. } & \multirow{2}{*}{$\begin{array}{c}\text { Duration } \\
\text { (days) }\end{array}$} \\
\hline & 1 & 2 & 3 & 4 & 5 & 6 & 7 & 8 & \\
\hline \multicolumn{10}{|l|}{ Bubalus bubalis } \\
\hline Riverine* & $27 \cdot 5$ & $12 \cdot 9$ & $20 \cdot 2$ & $10 \cdot 2$ & $2 \cdot 1$ & $7 \cdot 1$ & $8 \cdot 3$ & $10 \cdot 3$ & $8 \cdot 6$ \\
\hline Swamp ${ }^{\dagger}$ & 23.9 & $13 \cdot 4$ & $18 \cdot 7$ & $9 \cdot 8$ & 1.9 & $8 \cdot 8$ & $10 \cdot 6$ & $12 \cdot 8$ & $8 \cdot 7$ \\
\hline Bos taurus $\ddagger$ & $29 \cdot 5$ & $13 \cdot 0$ & $19 \cdot 3$ & 11.6 & $1 \cdot 7$ & $6 \cdot 2$ & $7 \cdot 6$ & $11 \cdot 0$ & $13 \cdot 5$ \\
\hline B. indicus & $31 \cdot 3$ & $12 \cdot 2$ & $21 \cdot 2$ & $8 \cdot 8$ & $4 \cdot 2$ & $5 \cdot 7$ & $6 \cdot 3$ & $10 \cdot 3$ & $14 \cdot 0$ \\
\hline B. indicus $\times$ B. taurus $\square$ & $29 \cdot 4$ & $12 \cdot 2$ & $20 \cdot 1$ & $6 \cdot 8$ & $1 \cdot 6$ & $5 \cdot 5$ & $8 \cdot 3$ & $15 \cdot 9$ & $13 \cdot 4$ \\
\hline B. sondaicus & $17 \cdot 9$ & $10 \cdot 0$ & $27 \cdot 4$ & $7 \cdot 6$ & 4.0 & $12 \cdot 8$ & $13 \cdot 2$ & $7 \cdot 1$ & 11.8 \\
\hline
\end{tabular}

*Means of frequency data of Guraya \& Bilaspuri (1976) and Sharma \& Gupta (1980). Duration estimate by Sharma \& Gupta (1980).

$\dagger$ McCool et al. (1989).

$\ddagger$ Means of frequency data of Ortavant (1959), Amann (1962) and Hochereau-de Reviers (1963, 1970). Duration estimate by Amann (1962).

§Cardoso \& Godinho (1983).

ๆ Salim \& Entwistle (1982).

Table 3. Durations of the seminiferous epithelial cycles of cattle of several species

\begin{tabular}{lcl}
\hline Species & $\begin{array}{c}\text { Duration } \\
\text { (days) }\end{array}$ & \multicolumn{1}{c}{ References } \\
\hline Bos taurus & 13.5 & Amann (1962) \\
B. indicus & 14.0 & Cardoso \& Godinho (1983) \\
$\begin{array}{l}\text { B. indicus } \times \text { B. taurus } \\
\text { Bubalus bubalis }\end{array}$ & 13.4 & Salim \& Entwistle (1982) \\
$\quad$ Riverine type & $8 \cdot 6$ & Sharma \& Gupta (1980) \\
Swamp type & 8.7 & McCool et al. (1989) \\
B. sondaicus & 11.7 & This study \\
\hline
\end{tabular}


$F_{1}$ B. taurus $\times$ B. sondaicus and $F_{1}$ B. indicus $\times$ B. sondaicus hybrid males are sterile (Kirby, 1979), and male progeny from $F_{1}$ females and from some later female crosses are commonly sterile or exhibit very low sperm production rates (unpublished data). The differences between each species in the relative frequencies of stages and substages of the cycle of the seminiferous epithelium and in the duration of the cycle may partly explain this phenomenon.

In some similar studies employing radiolabelling of the seminiferous epithelium in other ruminants, seminiferous epithelial degeneration has been noted (Ross \& Entwistle, 1979; Salim \& Entwistle, 1982; McCool et al., 1989). In a study of the cycle of the seminiferous epithelium in the swamp buffalo (McCool et al., 1989), testes which had been injected with tritiated thymidine via the testicular artery were rendered unsuitable for examination if more than 5 days elapsed between injection and sampling, since the seminiferous epithelial degeneration was too severe to allow accurate identification of tubule stages and substages. The causes have never been identified. The trauma and inflammation associated with exposure of the testicular artery may have been at least partly responsible. The above considerations prompted selection of the direct injection technique in the current study, and all samples were collected within 5 days. Direct injection into the testicular parenchyma proved much simpler, entailed less surgical trauma, and resulted in good specific labelling.

I thank M. Simpson, T. Olm and H. Rainger for technical assistance; and H. Brown and V. Lilley for preparation of histological sections.

\section{References}

Amann, R.P. (1962) Reproductive capacity of dairy bulls. III. The effect of ejaculation frequency, unilateral vasectomy and age on spermatogenesis. $\mathrm{Am}$. J. Anat. 110, 49-62.

Berndtson, W.E. \& Desjardins, C. (1974) The cycle of the seminiferous epithelium and spermatogenesis in the bovine testis. Am. J. Anat. 140, 167-180.

Cardoso, M.P. \& Godinho, H.P. (1983) The cycle of the seminiferous epithelium and its duration in the Zebu, Bos indicus. Anim Reprod. Sci. 5, 23I-245.

Courot, M., Hochereau-de Reviers, M.T. \& Ortavant, R. (1970) Spermatogenesis. In The Testis. Vol. 1, pp. 229. 432. Eds A. D. Johnson, W. R. Gomes \& N. L. VanDemark. Academic Press, New York.

Guraya, S.S. \& Bilaspuri, G.S. (1976) Stages of seminiferous epithelial cycle in buffaloes (Bos bubalis). Annls Biol. anim. Biochim. Biophys. 16, 137-144.

Hochereau-de Reviers, M.T. (1963) Constance des frequences relatives des stades du cycle de l'epithelium seminifre chez le taureau et chez le rat. Annls Biol. anim. Biochim. Biophys. 3, 93-102.

Hochereau-de Reviers, M.T. (1970) Etude des divisions spermatogoniales souche chez le taureau. D.Sc. thesis, University of Paris, Paris. [Cited by Berndtson \& Desjardins (1974).]

Kirby, G.W.M. (1979) Bali cattle in Australia. Wld Anim. Rev. 31, 2-7.
McCool, C.J., Entwistle, K.W. \& Townsend, M.P. (1989) The cycle of the seminiferous epithelium in the Australian swamp buffalo. Theriogenology 31, $399-417$.

Ortavant, R. (1959) Spermatogenesis and morphology of the spermatozoon. In Reproduction in Domestic Animals, Ist edn, pp. 1-50. Eds H. H. Cole \& P. T. Cupps. Academic Press, New York.

Payne, W.J.A. \& Rollinson, D.H.L. (1973) Bali cattle. Wld Anim. Rev. 7, 13-21.

Roosen-Runge, E.C. \& Giessel, L.O. (1950) Quantitative studies on spermatogenesis in the albino rat. Am. $J$. Anat. 87, 1-30.

Ross, A.D. \& Entwistle, K.W. (1979) The effect of scrotal insulation on spermatozoal morphology and the rates of spermatogenesis and epididymal passage of spermatozoa in the bull. Theriogenology 11, 111-129.

Rowley, M.J. \& Heller, C.G. (1966) The testicular biopsy: surgical procedure, fixation and staining techniques. Fert. Steril. 17, 177-186.

Salim, B. \& Entwistle, K.W. (1982) Duration of the seminiferous epithelial cycle in Bos indicus $\times$ Bos taurus bulls. J. Reprod. Fert. 66, 729-734.

Sharma, A.K. \& Gupta, R.C. (1980) Duration of seminiferous epithelial cycle in buffalo bulls (Bubalus bubalis). Anim. Reprod. Sci. 3, 217-224.

Received 6 February 1989 